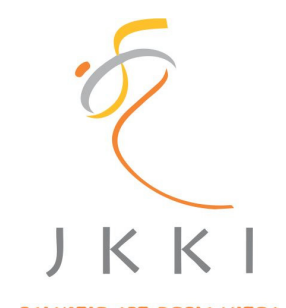

Jurnal Kedokteran dan Kesehatan Indonesia

Indonesian Journal of Medicine and Health

Journal homepage: https://journal.uii.ac.id/JKKI

SCIENTIR EST BASIC VITAE

\title{
Microbial approach of epitope tagged MFE-23 single fragment antibodies production
}

\author{
Razmaeda Sarastry*1 \\ ${ }^{1}$ Mutiara Bunda Maternal and Child Hospital Salatiga, Salatiga, Indonesia
}

Original Article

\begin{tabular}{l}
\hline \\
\hline ART ICLE I NF O \\
\hline Keywords: \\
scFv-MFE \\
CEA \\
E. coli \\
ELISA \\
*Corresponding author: \\
razmaeda@gmail.com \\
\hline DOI: 10.20885/JKKI.Vol11.Iss3.art3 \\
\hline History: \\
Received: February 27, 2019 \\
Accepted: November 25, 2020 \\
Online: December 31, 2020 \\
\hline Copyright @2020 Authors. \\
This is an open access article \\
distributed under the terms \\
of the Creative Commons At- \\
tribution-NonCommercial 4.0 \\
International Licence (http:// \\
creativecommons.org/licences/ \\
by-nc/4.0/).
\end{tabular}

ABSTRACT

Background: Antibodies have been investigated for future clinical application in cancer management. An antibody, MFE-23 scFv is known for its ability to bind Carcinoembryonic Antigen (CEA). Different from a full length antibody, single-chain variable fragments (scFvs) are recombinant antibodies in which single polypeptide is engineered to replace variable regions encoding antigen-binding domain. In vitro production of single chain fragment antibodies may use E. coli microorganism for its ability to self-replicating a plasmid.

Objective: This study aimed to produce his- and myc- tagged MFE- $23 \mathrm{scFv}$ antibodies by using E. coli culture and to detect their solubility by using ELISA assay.

Methods: Transformed E. coli containing sequences of MFE-23 coding were inoculated and evaluated for their optical density. An ELISA plate was coated by CEA or PBS and secondary antibodies were anti-his, antimyc and anti-MFE. Horseradish peroxidase-OPD substrate was added to produce chromatic reaction for qualitative detection.

Results: The results showed that each characterized tube was positive for myc-tagged MFE, his- and myc- tagged MFE, and his-tagged MFE for tube 1,2 , and 3 respectively.

Conclusion: This study indicated that transformed E. coli culture is a suitable host for MFE-23 svFV production, and qualitative ELISA assay is a simple useful method for antibody detection and characterization of single chain antibodies.

Latar Belakang: Antibodi terus diselidiki untuk penerapan klinis di masa depan dalam manajemen kanker. Antibodi MFE-23 scFv dikenal karena kemampuannya untuk mengikat CEA. Berbeda dari antibodi panjang penuh, fragmen variabel rantai tunggal (scFvs) adalah antibodi rekombinan di mana polipeptida tunggal direkayasa untuk menggantikan daerah variabel yang mengkode domain pengikatan antigen. Produksi in-vitro dari antibodi fragmen rantai tunggal dapat menggunakan mikroorganisme E. coli untuk kemampuannya mereplikasi diri sendiri dalam plasmid.

Tujuan: Penelitian ini bertujuan untuk menghasilkan antibodi MFE-23 scFv dan myc-tag menggunakan kultur E. coli dan mendeteksi bentuk larutnya menggunakan uji ELISA.

Metode: E. coli yang ditransformasi mengandung urutan pengkodean MFE-23 yang diinokulasi dan dievaluasi densitas optiknya. Plat ELISA dilapisi oleh CEA atau PBS dan antibodi sekunder yang digunakan adalah anti-his, anti-myc dan anti-MFE. Substrat peroksidase-OPD lobak ditambahkan untuk menghasilkan reaksi kromatik untuk deteksi kualitatif. 
Hasil: Hasil karakterisasi setiap tabung adalah positif untuk MFE yang diberi tag myc, MFE yang diberi tag dan myc-tag, dan antibodi MFE yang diberi tag untuk masing-masing tabung 1, 2, dan 3.

Kesimpulan: Kultur E. coli yang ditransformasikan adalah inang yang sesuai untuk produksi antibodi MFE-23 svFV, dan uji ELISA kualitatif adalah metode sederhana yang berguna untuk deteksi antibodi dan karakterisasi antibodi rantai tunggal.

\section{INTRODUCTION}

A cancer results from genetic dysregulation of normal cell as well as inflammation state to support their microenvironment. ${ }^{1}$ For decades, some approaches for cancer therapies are often conducted conventionally by, for example, surgery, radiation, and chemotherapy. These approaches emphasize on direct cytotoxicity towards cancer cells although these conventional therapies can also destroy normal tissues in the body. Therefore, cancer researches tend to focus on the targeted therapies such as development of single chain antibodies with potentially better efficacy and lower toxicity to other normal tissues. ${ }^{2}$

Antibodies are produced by mature B cells to fight foreign antigens, including malignant cells which express distinctive antigens on their cell surface. ${ }^{3,4}$ They are Y-shaped molecules consisting of three proportioned-sized parts and linking loosely each other in the middle. Heavy and light chains are combined to constitute variables and constant regions of the antibodies. The antigen-binding site is positioned at a complement determining the region (CDR) on the tip of the variable regions. ${ }^{3}$ Initially, a cancer therapy using antibody is to tag malignant cells as foreign, and to launch the cytotoxic immune cells to attack them. However, this approach seems to have low specificity to the cancerous cells. To achieve higher specificity of antibody based on therapies, conjugations of antibodies to various agents such as toxins and radionuclides are developed. ${ }^{2}$

Carcinoembryonic antigens of a colorectal tumor have been extensively studied in tumor-associated antigens. ${ }^{5}$ They are initially presented as fetal protein, but they can exist in some adult normal epithelial tissues such as tongue, esophagus, stomach, colon, sweat glands, prostate, and cervix. ${ }^{6,7}$ Distribution and concentration levels of CEA in cells indicate cancer transformation. ${ }^{7}$ Due to its distinction on distribution and levels in cancer cells compared to normal cells, CEA can be targeted as a marker to detect the tumor development and immunotherapy using anti-CEA antibodies. ${ }^{6}$

The smallest entity of an antibody molecule for binding the antigens is the Fv fragment. ${ }^{8} \mathrm{~A}$ flexible peptide linker associates to the light and heavy chains of the variable regions in a single chain fragment variable scFv antibody construct (Figure 1). This form of antibody can be engineered and expressed in E. coli bacteria. ${ }^{9}$

MFE-23 is an antibody with a high affinity to CEA and is known as the initial scFV used in clinics. The first MFE-23 is obtained

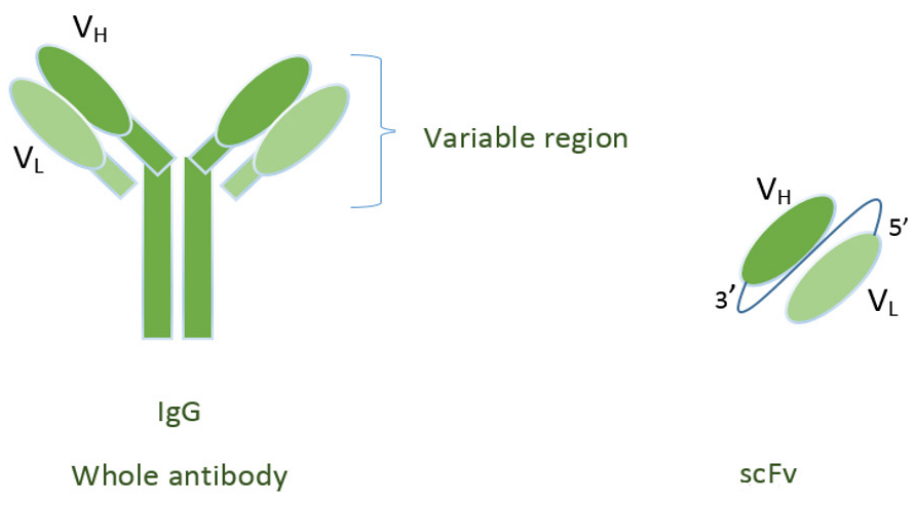

Figure 1. Model of antibody presenting the subunit component. scFv absence of the constant regions. 
from a CEA-immunized mouse resulting in a filamentous phage expression library of randomly formed pairings of VH-VL domain. ${ }^{10}$ A previous study showed that MFE-23 can be expressed in $E$. coli by sub-cloning its coding sequences into a bacterial plasmid. The C-terminus of produced MFE-23 can be attached to various tags for protein detection and characterization..$^{11}$ The produced antibodies can be detected by using various methods such as immunoblotting, latex agglutination, enzymelinked immunosorbent assay, and micro-particle enzyme immunosorbent assay. However, these assays provide different performance in terms of affordability and simplicity. ${ }^{12}$

This study aims to produce his- and myctagged scFV MFE-23 antibodies in E. coli bacteria cultures and to detect their presence by using qualitative indirect ELISA assay.

\section{METHODS}

This study is a true experimental research with post-test only design. This used transformed E. coli containing sequences of MFE-23 coding with his- and/or myc- tag on its single chain antibody fragment. A double fusion tag for protein (his-/myc) was developed to obtain better purification of beneficial recombinant proteins when extensive protein characterization is not possible. The construct was provided by Cancer Institute laboratory, University College London. The flow diagram of the experiment can be seen in Figure 2 .

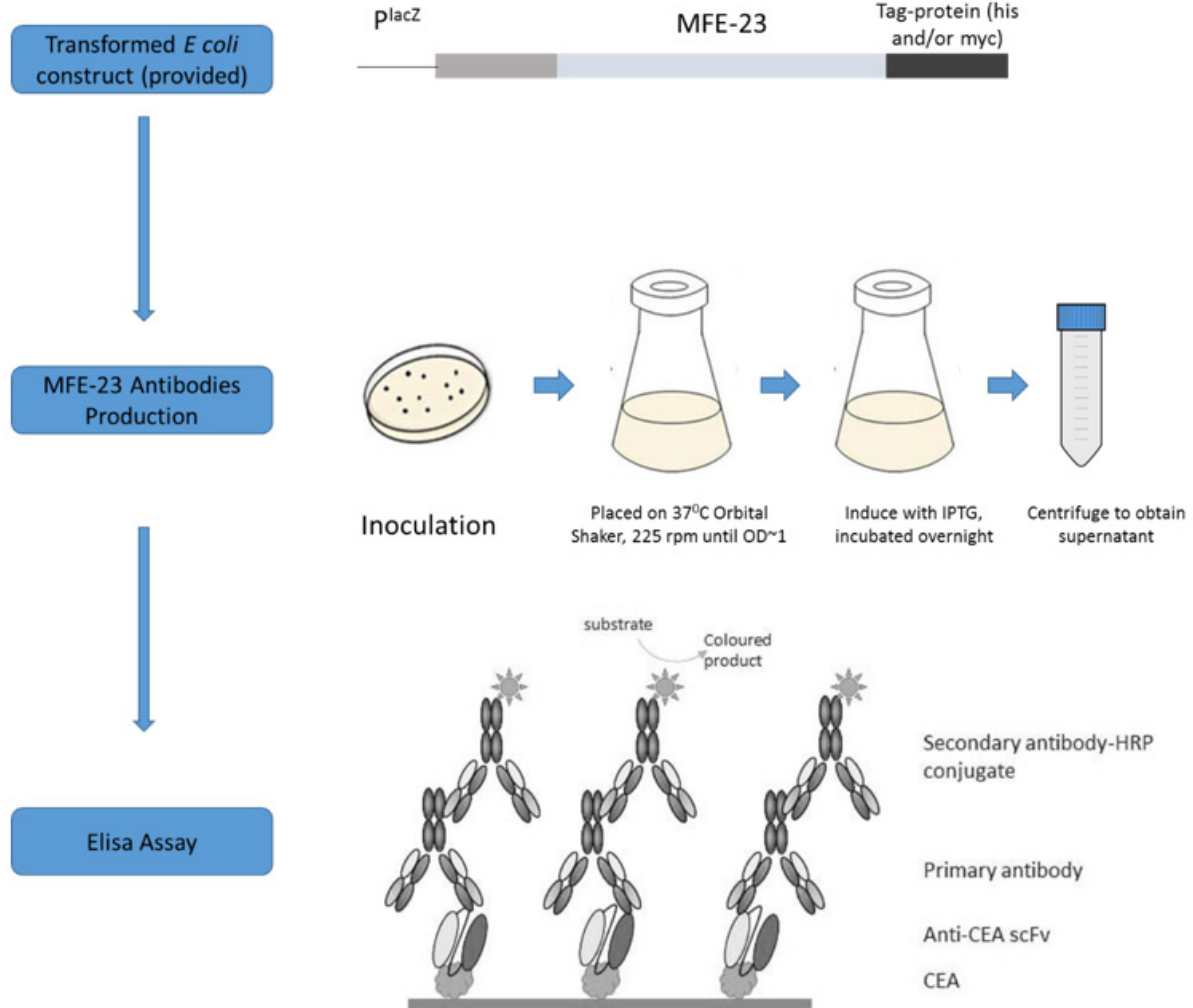

Figure 2. The flow diagram of the experiment was first started by inoculating the transformed E coli (previously provided) with growth media which then induced with IPTG to produce antibody. The culture was centrifuged to obtain supernatant for ELISA assay.

\section{Production of MFE-23 antibodies}

Into three different tubes containing growth media (2TY), ampicillin and $0.5 \%$ glucose, the
E. coli cultures were inoculated, with $200 \mu \mathrm{l}$ for each tube. One tube containing only growth media (2TY) was used as a negative control. 
The tubes were placed on $37^{\circ} \mathrm{C}$ orbital shaker and were shaken at $225 \mathrm{rpm}$. The growth of E. coli cultures was checked constantly every 30 minutes for optical density measurement by using a spectrophotometer at $600 \mathrm{~nm}$ to determine growth curves. When OD600 was approaching $0.9,20 \mu \mathrm{l}$ of $1 \mathrm{M}$ isopropyl- $\beta$-D-1thiogalactopyranoside (IPTG, Sigma Aldrich, USA) was added to induce the antibody production. The tubes were then incubated overnight on the shaker at $30^{\circ} \mathrm{C}$ and 225 rpm. After incubation, the cultures were centrifuged at $18.000 \mathrm{G}$ for 20 minutes to obtain supernatants for ELISA.

\section{Elisa assay}

CEA (R\&D) at a concentration of $1 \mu \mathrm{g} / \mathrm{ml}$ was added into half of 96-well ELISA plate. To each well of the other half ELISA plate was added with phosphate-buffered saline (PBS). The plate was covered and incubated for 1 hour at a room temperature. The wells were rinsed by PBS, added by $5 \%$ blocking solution (Marvel milk/PBS) and sealed with a plastic film for overnight incubation at $4^{\circ} \mathrm{C}$. After incubation, the plate was rinsed by PBS. Supernatants of each sample were pipetted in triplicate. Three different antibodies of primary detection were used: rabbit anti-MFE-23 polysera, rabbit anti-myc (Sigma Aldrich, USA) and mouse monoclonal anti-his-tag (Sigma Aldrich, USA). Each antibody was diluted 1:1000 in $1 \%$ blocking solution. Each type antibody was pipetted to each well coated with CEA or PBS. The plate was incubated for 1 hour. The wells were rinsed twice with $0.1 \%$ PBS/Tween and PBS, and secondary antibody was administered.

In this experiment, the author used two horseradish peroxidase (HRP) conjugated antibodies reactive with the primary detection antibodies: goat anti-rabbit HRP (Sigma Aldrich, USA) diluted 1:1000 in 1\% blocking solution and sheep anti-mouse HRP (Sigma Aldrich, USA) diluted 1:1000 in 1\% blocking solution.

$100 \mu \mathrm{l}$ of each antibody was added to corresponding wells; anti-mouse HRP for antihis wells and anti-rabbit HRP for anti-MFE-23 and anti-myc wells. The plate was incubated for 1 hour at a room temperature. The wells were rinsed twice with $0.1 \%$ PBS/Tween and PBS.

$100 \mu \mathrm{l}$ prepared O-Phenylenediamine Dihydrochloride (OPD) substrate buffer (Sigma Aldrich USA) was added to each well. After colorization occurred, $50 \mu \mathrm{l}$ of $4 \mathrm{M} \mathrm{HCl}$ was added to stop the reaction. The plate was read at OD450 by using an automated plate reader. A cut off value to determine positive results was obtained from the mean and standard deviation of negative controls. The sample with optical density more than the addition of OD mean with three multiply by standard deviation of the negative control was indicated as positive result.Cut off value $=$ OD +3 SD .

\section{RESULTS}

\section{E. coli growth curves}

The curves illustrated the dynamic of the $E$. coli growth by plotting the absorbance on $\mathrm{Y}$ axis versus incubation period on the $\mathrm{X}$-axis (Figure 2). The lag phases without visible replication or size increase were slightly different between tube 1 and the remains. Lag phase for tube 1 was at $t=0-60$, while the tube 2 and 3 were same at $\mathrm{t}=0$-30. Exponential phases when bacterial continue to grow in double were from $t=30$, $t=30$, and $t=60$ for tube 2,3 and 1 respectively. Generation time referred to the time needed for bacteria to generate was 30 minutes, and it was same for all tubes. At $=150$, tube 3 reached OD $\neg 600=0.680$; the culture was stopped, and IPTG was added to induce MFE-23 production. The remaining tubes were stopped at $\mathrm{t}=180$ with OD600 readings were 0.625 and 0.794 for tube 1 and 2 respectively (Table 1 ).

\section{Elisa assay}

Positive outcome occurred as colorization changed from yellow to orange. On the CEA coated wells, MFE-his-myc antibody as a positive control indicated colorization, and 2TY medium only as a negative control showed no colorization. Additionally, the PBS negative control at the other half of the plate showed accurately low reading of OD without visible colorization. The author 
Table 1 . The absorbance reading of each tube every 30 minutes to determine the growth curve

\begin{tabular}{cccc}
\hline \multirow{2}{*}{ Time } & \multicolumn{3}{c}{ Absorbance (0D600) } \\
\cline { 2 - 4 } & Tube 1 & Tube 2 & Tube 3 \\
\hline 30' & 0.025 & 0.025 & 0.026 \\
$60^{\prime}$ & 0.033 & 0.047 & 0.057 \\
$90^{\prime}$ & 0.055 & 0.091 & 0.143 \\
$120^{\prime}$ & 0.121 & 0.196 & 0.335 \\
$150^{\prime}$ & 0.33 & 0.488 & 0.68 \\
$180^{\prime}$ & 0.625 & 0.794 & (stopped) \\
\hline
\end{tabular}

\section{E. coli growth curves}

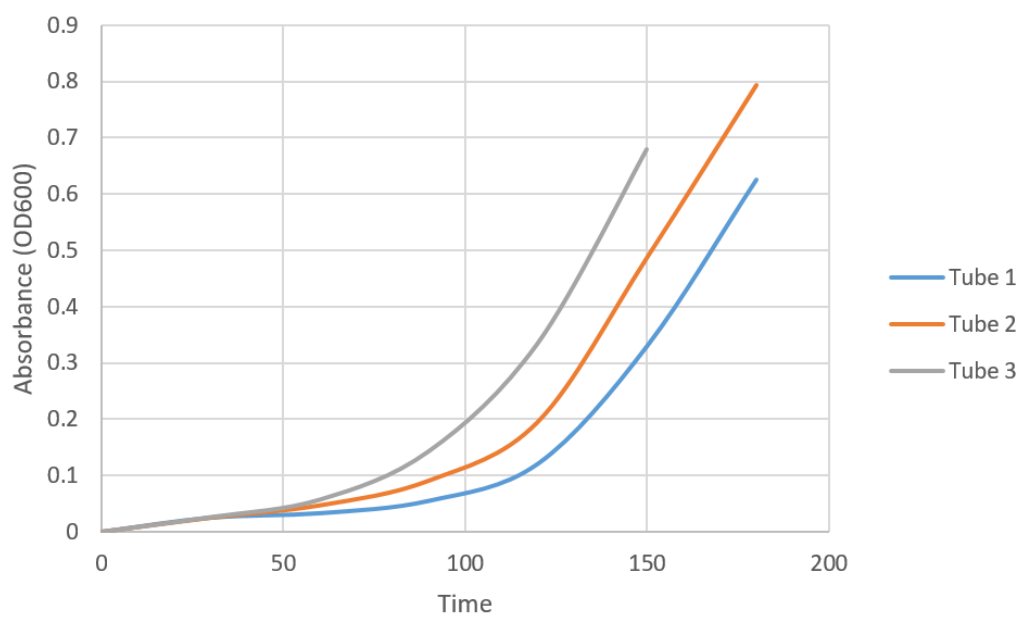

Figure 2. E coli growth curves follow the exponential patterns.

tested 3 different tubes of previous bacterial culture to determine the contained antibodies for each tube. Qualitatively, tube 1 and 2 displayed colorization after substrate addition for anti-his and anti-myc antibodies. Meanwhile, tube 3 was positive for anti-his antibody only.

The absorbance reading at OD450 of each sample in the three tubes was also corresponded to the colorization result. The obtained cut off value from the negative control was 0.067 . The samples with OD value more than 0.067 were positive for the corresponding antibodies. Tube 1 and tube 2 were tested positive for the presence of both his- and myc- tagged antibodies. Meanwhile, tube 3, was only positive for the presence of his-tagged antibody (Table 2).

Table 2. The ELISA results for each tube

\begin{tabular}{lcccl}
\hline Tube & Antibody & OD (mean) & Result & Cut off value \\
\hline Tube 1 & his-tagged & 0.666 & positive & \\
& myc-tagged & 0.728 & positive & OD+3SD $=$ \\
Tube 2 & his-tagged & 0.982 & positive & $0.0512+3(0.0167)$ \\
& myc-tagged & 0.867 & positive & $=0.067$ \\
Tube 3 & his-tagged & 0.777 & positive & \\
& myc-tagged & 0.04 & negative & \\
\hline
\end{tabular}




\section{DISCUSSION}

In this study, the author performed in vitro production of a single fragment antibody. Singlechain variable fragments are recombinant antibodies in which single polypeptide is engineered to replace the variable regions encoding antigen-binding domains. The author used microbial approach to produce the MFE scFv antibodies. Recently, there have been microorganisms commonly used to express antibody fragment including yeast $S$. cerevisiae, yeast $P$. pastoris, and bacterium E. coli. ${ }^{13}$

In this study, all the E. coli cultures were growing exponentially despite their differences in the logarithmic phase starts. Tube 2 and 3 were faster in entering log phase than tube 1. It might be due to the different number of inoculated $E$. coli on each tube. Bacteria cultures in this study were discontinued when 0D600 readings were approximately 0.7. Discontinuing at OD600 $=0.7$ was critical because a longer period of culture might lead bacteria to enter the stationary phase which was likely to happen at OD600>0.9.14 Stationery phase happens when the bacteria are starving due to medium decrease. This happens in waste products that shift condition such as $\mathrm{pH}$ and temperature and decrease the antibody production. ${ }^{15}$

Overall, there are two main methods of antibodies production; in vivo and in vitro production. In vivo production often involves animal models which may produce antibodies in higher concentration with certain advantage such as glycosylation. However, this method is expensive and may raise some bio-ethical concerns..$^{16}$ On the other hand, in vitro method may offer different advantages such as the possibility of producing large-scale of antibodies in a relatively short time and the simple purification process. Some techniques used in this particular method include mammalian cell culture and bioreactors. ${ }^{17}$

MFE scFv, unlike the full-length antibodies, is not glycosylated. Therefore, the use of commonly mammalian cells to produce the full-length antibody is not suitable to perform in a case of antibody fragment. However, these small proteins still possess their antigen binding features; hence, they can be scaled up in microbial organism. There are several advantages of using microorganisms in producing proteins such as antibodies. This modality performs highly selective reactions by their own enzymatic machinery which are difficult to attain by chemical reaction. ${ }^{18}$ Besides, use of microorganisms is easily replicated with relatively lower production cost. Additionally, the use of microbial agents does not produce pollutant either organically or inorganically. ${ }^{19}$

The expression of protein is commonly driven by self-replicating plasmid containing robust promoter such as the bacteriophage $\mathrm{T} 7$, the synthetic tryptophan operon (trp) promoter, or the E. coli lactose operon (lac). In this study, E. coli was used by following an insertion of the sequences of MFE-23 coding into a bacterial plasmid (pUC119). ${ }^{20}$ This plasmid expression allows the soluble MFE-23 to be isolated directly from the supernatant of bacterial cultures. Subsequently, different tags can be attached on the C-terminus, for example hexahistidine tag (his- tag) or myc- tag for the detection and purification of the antibodies. ${ }^{11}$

As described in other studies, recombinant protein are commonly cloned in adjacent to Lac-Z operon which is inducible by IPTG, a lactose analogue. ${ }^{20}$ Therefore in this study, the scFv antibodies were cloned in the same location to obtain MFE-23 expression.

ELISA is often used to detect the presence of antibody that is coupled to an enzyme and to assess the interaction of a specific antibody to a certain antigen. Detection is performed by evaluating the activity of conjugated enzyme following incubation process. ${ }^{21}$ Use of ELISA is not limited to the full-length antibody detection. Moreover, this method can be used to identify single chain variable fragment antibody against immunodominant membrane protein (IMP) in plants. ${ }^{22}$

In this study, indirect ELISA was conducted to qualitatively detect the produced MFE- $23 \mathrm{scFv}$ antibody, involving a two-step binding process of primary antibody and HRP secondary antibody. Substrate addition which was immediately 
hydrolysed produced visible yellow-orange colorization as occurred on all the tubes for the anti-MFE antibody. This was what was expected because MFE antibodies were produced on the supernatant of all $E$. coli culture regardless their specific tags on its $\mathrm{C}$-terminus. The absorbance readings on this experiment may not correlate with antibody concentration on each sample. The difference on absorbance, however, could happen due to artifacts or technical issues of each reading. ${ }^{23,24}$

Although the expression system of $E$. coli bacteria is well-understood and has been widely used to express various recombinant proteins, butthere are also some drawbacks around it. ${ }^{25}$ The highly active self-replicating plasmid machinery in bacteria may cause a serious metabolic load for the E. coli such as cell growth arrest and apoptosis.

Until now, more than $40 \%$ of antibodies clinically tested for therapeutics are in forms of antibody fragments. The most advanced examples are anti-TNF $\alpha$ scFv, ESBA-105 entering phase- 1 clinical trial for ophthalmic use, and Efungumab connecting to the Candida albicans heat shock protein is into the phase-2 development. ${ }^{25}$ MFE- $23 \mathrm{scFv}$, a potential tool for cancer detection is an important step related to the patient management. CEA level was shown to be high in case of primary colorectal cancer and early metastatic disease to the liver. ${ }^{26}$ This tumor-associated antigen is known for its immunogenicity capable to trigger circulating antibody production against CEA. ${ }^{24}$ Scaling up the antibody production will benefit the biomedical use for diagnose and therapeutic. Besides, detection of this antibody can be achieved by using simple ELISA technique which is sensitive and specific, relatively easy, low cost, and it has been extensively used in clinical setting. ${ }^{21}$

\section{CONCLUSION}

It can be seen that MFE- $23 \mathrm{scFv}$, a single fragment antibody which recognizes CEA antigen can be produced in E. coli bacterial culture. The rapid growth of E. coli and its ability to obtain high density of cells are beneficial for this study. The produced MFE-23 antibody that can be detected by using indirect ELISA showed that the binding of small molecule to antibody would not influence its specificity to certain antigens.

\section{CONFLICT OF INTEREST}

No relevant disclosures.

\section{ACKNOWLEDGEMENT}

The author would like to thank to Cancer Institute University College London, Professor Kerry Chester for her broad and deep knowledge and to thank to Enrique Miranda, Alex Kinna, Maria Livanos, and Fatemeh Vahid for their help during the laboratory work.

\section{REFERENCES}

1. Hanahan D, Weinberg RA. Hallmarks of cancer: The next generation. Cell. 2011;144(5):646-74.

2. Carter P. Improving the efficacy of antibody-based cancer therapies. Nature Reviews Cancer. 2001;1(2):118-29.

3. Murphy KM, Travers P, Walport M (Eds.) Janeway's immunobiology. 8 edition. New York:Taylor \& Francis, Inc; 2010.

4. Li J, Zhu Z. Research and development of next generation of antibody-based therapeutics. Acta Pharmacologica Sinica. 2010;31:1198-207.

5. Ou G, Baranov V, Lundmark E, Hammarström S, Hammarström ML. Contribution of intestinal epithelial cells to innate immunity of the human gut--studies on polarized monolayers of colon carcinoma cells. Scandinavian Journal of Immunology. 2009; 69(2):150-61.

6. Nap M, Mollgard K, Burtin P, Fleuren GJ. Immunohistochemistry of carcino-embryonic antigen in the embryo, fetus and adult, Tumor Biology. 1988;9:145-53.

7. Berinstein NL. Carcinoembryonic antigen as a target for therapeutic anticancer vaccines: A review. Journal of Clinical Oncology. 2002;v20(8):2197-207.

8. Hammarstrom $\mathrm{S}$. The carcinoembryonic antigen (CEA) family: Structures, suggested functions and expression in normal and malignant tissues. Seminars in Cancer Biol- 
ogy. 1999;9:67-81.

9. Hammers CM, Stanley JR. Antibody phage display: Technique and applications. The Journal of Investigative Dermatology. 2014;134(2):1-5.

10. Butler M, Meneses-Acosta A. Recent advances in technology supporting biopharmaceutical production from mammalian cells. Applied Microbiology and Biotechnology. 2012;96:885-94.

11. Chester KA, Begent RHJ, Robson L, Keep PA, Pedley RB, Boden JA, et al. Phage libraries for generation of clinically useful antibodies. Lancet. 1994;343:455-56.

12. Spadiut O, Capone S, Krainer F, Glieder A, Herwig C. Microbials for the production of monoclonal antibodies and antibody fragments. Trends in Biotechnology. 2014;32(1):54-60.

13. Madigan MT, Martinko JM, Parker J. Brock biology of microorganisms. 2000. 135-162 p.

14. Kolter R, Siegele DA, Tormo A. The stationary phase of the bacterial life cycle. Annual Review of Microbiology. 1993;47:855-74.

15. Abebe M, Kumar V, Sevinc S, Vijay HM. Comparison of monoclonal antibodies produced by in vitro and in vivo methods. Journal of Allergy and Clinical Immunology. 2004;113(2, Suppl).

16. Marx U, Embleton MJ, Fischer R, Gruber FP, Hansson U, Heuer J, et al. Monoclonal antibody production. ATLA-NOTTINGHAM. 1997;25:121-38.

17. Bolivar JM. Shine a light on immobilized enzymes: Real-time sensing in solid supported biocatalysts. Trends in Biotechnology. 2013;31:194-203.

18. Chelliapan S, Sallis PJ. Removal of organic compound from pharmaceutical wastewater using advanced oxidation processes. Journal of Scientific and Industrial Research. 2013;72:248-54.

19. Narang A, Oehler S. Effector overlap between the lac and mel Operons of Escherichia coli: Induction of the mel Operon with $\beta$-Galactosides. Journal of Bacteriology. 2017;199(9):e00796-16.

20. Lequin R. Enzyme immunoassay (EIA)/en- zyme-linked immunosorbent assay (ELISA) Clinical.Chemistry. 2005;51:2415-8.

21. Shahryari F, Safarnejad MR, Shams-Bakhsh M, Schillberg S, Nölke G. Generation and expression in plants of a single-chain variable fragment antibody against the immunodominant membrane protein of Candidatus phytoplasma aurantifolia. Journal of Microbiology and Biotechnology. 2013;23(8):1047-54.

22. Burgess C. Chapter 1 . The basics of spectrophotometric measurement, techniques and instrumentation in analytical chemistry. Elsevier. 2007;27:1-19.

23. Jost M, Latz A, Ballhorn W, Kempf VAJ. Development of a specific and sensitive enzyme-linked immunosorbent assay as an in vitro diagnostic tool for detection of Bartonella henselae antibodies in human serum. Journal of Clinical Microbiology. 2018;56(12):e01329-18.

24. Walsh G. Biopharmaceutical benchmarks. Nature Biotechnology. 2010;28:917-24.

25. Nelson AL. Antibody fragments: Hope and hype. mAbs. 2010;2(1):77-83.

26. Duffy MJ. Carcinoembryonic antigen as a marker for colorectal cancer: Is it clinically useful? Clinical Chemistry. 2001;47(4):62430 . 